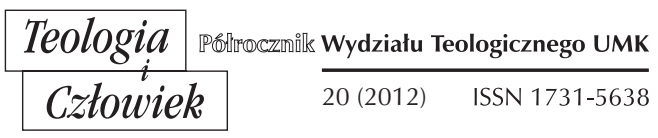

KS. DARIUSZ KWIATKOWSKI*

POZNAŃ-KALISZ

\title{
43. SYMPOZJUM JÓZEFOLOGICZNE KALISZ, 12 MAJA 2012 ROKU
}

Inauguracją 43. Sympozjum Józefologicznego, które odbyło się 12 maja 2012 roku w Kaliszu, była uroczysta Eucharystia koncelebrowana pod przewodnictwem ks. bp. Stanisława Napierały w kaplicy Cudownego Obrazu Świętego Józefa Kaliskiego (w bazylice św. Józefa). Na początku Mszy Świętej kustosz sanktuarium Świętego Józefa ks. prałat Jacek Plota powitał zebranych gości i pielgrzymów. Ksiądz Biskup w homilii odniósł się do tematu tegorocznego sympozjum: "Święty Józef i nowa ewangelizacja", podkreślając jego dwa aspekty. Po pierwsze, że temat nowej ewangelizacji jest obecnie bardzo aktualny, gdyż jesienią odbędzie się synod biskupów poświęcony temu zagadnieniu. Po drugie, że istnieje realny związek treściowy między św. Józefem i nową ewangelizacją. Biskup Napierała zauważył: „Bez św. Józefa, bez jego przekazu, który znalazł się ostatecznie w Ewangelii, nie wiedzielibyśmy o pewnych uwarunkowaniach, których Bóg chciał dla wcielenia Syna Bożego. [...]

${ }^{*}$ Ks. dr hab. Dariusz Kwiatkowski - kapłan diecezji kaliskiej, ur. 29.10.1963 r. we Włocławku. Obecnie pracuje w Wyższym Seminarium Duchownym w Kaliszu i jest adiunktem Wydziału Teologicznego na Uniwersytecie im. A. Mickiewicza w Poznaniu. Jest redaktorem naczelnym „Kaliskich Studiów Teologicznych". 
Wcielenie to jest poprzedzone małżeństwem. Na małżeństwie Józefa i Maryi Bóg oprze rodzinę swojego Syna - Zbawiciela i zadanie, jakie otrzymuje św. Józef. On ma stworzyć tej rodzinie warunki życia i rozwoju. [...] On ma być dla Jezusa wychowawcą, ma być głową tej rodziny. [...] Bóg czyni to małżeństwo fundamentem rodziny Jezusa. Józef jest patronem małżeństw, jest patronem rodziny i życia. Józef bronił życia Jezusa i Maryi, jeśli była taka potrzeba. Właśnie małżeństwo, rodzina, życie to dziedziny, którym dzisiaj szczególnie patronuje św. Józef, to są też dziedziny dzisiaj szczególnie zagrożone, a przecież są fundamentem. W tym całym zagubieniu św. Józef jest światłem i mówi: uważajcie na rodzinę, na życie, na małżeństwo mężczyzny i kobiety".

Zanim rozpoczęły się wykłady, Ksiądz Biskup poświęcił tablicę na budynku Centrum Józefologicznego upamiętniającą X Kongres Józefologiczny, który odbył się w 2009 roku, a następnie także nowe pomieszczenia przystosowane i przeznaczone do spotkań naukowych. Po modlitwie oficjalne słowo powitania wygłosił ks. prałat Andrzej Latoń, prezes Polskiego Studium Józefologicznego w Kaliszu i dyrektor Centrum Józefologicznego.

Pierwszy referat na 43. Sympozjum Józefologicznym wygłosił ks. mgr lic. Stanisław Szupieńko z Krzeszowa. Jego wystąpienie było zatytułowane: „Artystyczna prezentacja postaci św. Józefa na tle barokowej myśli teologiczno-biblijnej". Źródłem jego refleksji były przedstawienia malarskie św. Józefa znajdujące się w kościele pw. św. Józefa w Krzeszowie. Na wstępie prelegent przedstawił krótko tło historyczne Śląska. Mówił między innymi, że Krzeszów to miejsce wielu znaczących wydarzeń historycznych, które działy się już od XIII wieku. Obejmowały one również wielkie dzieło duchowe i religijne, opactwo cysterskie w Krzeszowie było bowiem jednym z najsławniejszych w środkowej Europie przez długie wieki. Opactwo krzeszowskie dzięki wielkim opatom, szczególnie z połowy XVII i XVIII wieku, stało się miejscem wielkich dokonań artystycznych, których realizatorami byli ówcześni najwięksi architekci, malarze, rzeźbiarze i wielu rzemieślników zatrudnianych przez opatów.

Już w XVII wieku powstały w Krzeszowie dzieła, które miały powiększać cześć św. Józefa. Antoni Szefler pisał, że opat Rosa, pragnąc udoskonalić naród, założył w tym celu bractwo oraz organizował pielgrzymki. Wydawał dla wiernych modlitewniki i tym samym nauczał o świętości życia i śmierci. Była to wtedy wielka ewangelizacja, po czasach spustoszenia Śląska przez reformację, a później przez wojnę 30-letnią. $\mathrm{Na}$ to zrealizowane z rozmachem dzieło, dla którego centralną postacią 
był św. Józef, opiekun Zbawiciela, złożyły się dwie główne inicjatywy Bernarda Rosy. Pierwszą było powołanie Bractwa św. Józefa, które rozrastając się w sposób lawinowy, na początku XVIII wieku liczyło około 100 tys. członków. Drugą inicjatywą była budowa kościoła brackiego i wykonanie we wnętrzu tej świątyni dekoracji malarskiej promującej osobę św. Józefa. Zbudowana w latach 1690-1696 świątynia nosząca wezwanie św. Józefa przez swoją barokową stylistykę i czytelne architektoniczne kształty wpisała się doskonale w szereg najświetniejszych budowli kościelnych na Śląsku.

Prelegent omówił także założenia ideologiczne malarstwa znajdującego się w kościele św. Józefa. Wnętrze tego kościoła, na zlecenie opata Rosy, Michael Willmann, największy śląski malarz barokowy, uczynił jakby czarodziejską szkatułą olśniewającą widza kunsztem malarskich przedstawień. Zachwycające wirtuozerią kompozycji, potokiem barw i wielości nastrojów, dzieło, które nie ma równych sobie, jest największym założeniem malarstwa freskowego na północ od Alp i największą malarską gloryfikacją osoby św. Józefa, opiekuna Zbawiciela. Tej gloryfikacji życia i osoby św. Józefa podporządkowano program ideowo-ikonograficzny kościoła. Prelegent podkreślił, że jest to bez wątpienia pomysł opata Rosy. Ten program swoją głębią i wypełnieniem teologiczno-biblijnym znajduje wielkie przepełnienie $\mathrm{w}$ malarskiej realizacji, a treści trynitarne, chrystologiczne, mariologiczne i józefologiczne zostały osadzone na szeroko pojętej tradycji biblijnej i apokryficznej.

Ksiądz Prałat zapewniał, że u podstaw ideowych monumentalnej polichromii freskowej w kościele św. Józefa stanęła ówczesna nauka o św. Józefie, którą przybliżał i propagował opat Rosa za pośrednictwem józefowego bractwa, modlitewników brackich. Trudno opisać dokładnie wszystkie elementy dzieł malarskich znajdujących się w tej świątyni, najlepiej zobaczyć je osobiście, do czego gorąco zachęcał prelegent. Ksiądz Stanisław podczas prezentacji starał się pobudzić wyobraźnię słuchaczy, omawiając obrazy wyświetlające się na ekranie i przyporządkowane na planie kościoła. Myślą przewodnią dekoracji umieszczonych w zwieńczeniu, w pierwszym przęśle nawowym świątyni, była teologiczna spekulacja dotycząca relacji zachodzących między niestworzoną Trójcą Świętą a trójcą stworzoną, którą tworzyli Jezus, Maryja i Józef, dlatego malarska wizja Gloria celestis wypełnia całą przestrzeń sklepienia chóru kościoła. W ostatnim przęśle nawowym cykl genealogii Chrystusa zamyka fresk prezentujący ziemską rodzinę Jezusa - Marię i Józefa. Te trzy postacie są kluczowymi osobami wątku dotyczącego trójcy stworzonej, 
zrealizowanego w dekoracji malarskiej tej świątyni brackiej. Punktem centralnym tego ciekawego obrazu o diagonalnej kompozycji jest postać małego dziecka - Jezusa, który na ramionach Maryi wychyla się i wyciąga ręce do św. Józefa. Ta niecodzienna scena ma niewątpliwie nobilitować osobę Józefa, gdyż w historii zbawczej pełnił on niezwykłą funkcję, będąc opiekunem Zbawiciela.

Cykl malowideł rozmieszczonych w kaplicach bocznych, przylegających od wschodu i od zachodu do nawy głównej, to barwne epickie opowiadanie. Zachwyca ono rozmachem konsekwentnie przedstawionych radosnych i smutnych epizodów z życia Józefa, mocno związanych z osobami Jezusa i Maryi. Urzekająca wszystkich fantazja twórcza autorów tych kilkudziesięciu obrazów jest widoczna przede wszystkim w przyjętej przez nich konwencji ikonograficznej, dzielącej przedstawienia obrazowe na radosne i smutne, realizującej równocześnie bardzo szczegółowo i zgodnie z chronologią biblijną kolejne etapy tzw. ewangelii dzieciństwa Jezusa. Ciekawym zabiegiem malarskim i kompozycyjnym jest umieszczenie biblijnych przedstawień i osób w XVII-wiecznych prowincjonalnych śląskich realiach, wśród żyjących w okolicach klasztoru ludzi i wśród otaczających Krzeszów podgórskich krajobrazów. Poza tym znane wydarzenia biblijne dotyczące dziecięcych lat Jezusa zostały wzbogacone dodatkowo apokryficznymi, a nawet antycznymi wątkami, które nie zakłóciły precyzyjnej prezentacji życiowych dokonań Józefa. Jedną z najbardziej urzekających scen jest przedstawienie zaślubin Maryi i Józefa, młodych małżonków, dla których Bóg przygotował swój plan. Na zakończenie ks. Stanisław Szupieńko stwierdził, że najlepiej można kontemplować artystyczne przedstawienia św. Józefa i Świętej Rodziny osobiście, w Krzeszowie.

Drugi referat wygłosił ks. dr Jacek Stefański, ojciec duchowny w Wyższym Seminarium Duchownym w Kaliszu oraz wykładowca egzegezy biblijnej i języka hebrajskiego. Jego wykład był zatytułowany: „Józefie, wstań, weź Dziecię i Jego Matkę i uchodź do Egiptu (por. Mt 2,13). Ale dlaczego do Egiptu?". Po przypomnieniu faktów biblijnych związanych z ucieczką Świętej Rodziny do Egiptu prelegent starał się odpowiedzieć na postawione $\mathrm{w}$ temacie referatu pytanie, dlaczego właśnie do Egiptu, a nie do innego miejsca anioł nakazał Józefowi zabrać Jezusa i Maryję. Już na początku swojego wystąpienia zaznaczył, że zadowalającą i wystarczającą odpowiedzią nie może być stwierdzenie, że jest to spełnienie słów proroka Ozeasza: „z Egiptu wezwałem syna mego” (Mt 2,15; por. Oz 11,1), ponieważ te słowa odnosiły się do wyjścia Izraelitów 
z Egiptu. To naród Izraela był określony przez Boga w Księdze Wyjścia mianem syna (Wj 4,22) i to Izraelitów Bóg już wyprowadził z Egiptu, wiele, wiele lat przed Chrystusem.

Szukając odpowiedzi na postawione pytanie, ks. dr Stefański przypomniał etymologię słowa "Egipt” w Starym Testamencie oraz znaczenie tego miejsca dla patriarchów Izraela, szczególnie dla Abrahama oraz Józefa egipskiego. Można powiedzieć, że na kartach Starego Testamentu Egipt jest ukazany albo jako miejsce schronienia przed uciskami, albo jako miejsce, które przyczyniło się do ucisków i prześladowań. Autor mówił, że Egipt był krajem, który ewidentnie już wcześniej wpisał się w dzieje wyznawców judaizmu nie tylko jako miejsce ucieczki przed głodem, ale również jako miejsce błogosławieństwa, zwłaszcza dla patriarchów Izraela. Stąd można stwierdzić, że udanie się św. Józefa wraz z Jezusem i Maryją do Egiptu zostało jakby zapowiedziane przez tymczasowe udanie się patriarchy Abrahama wraz z żoną Sarą do Egiptu ze względu na głód w ziemi Kanaan i przez udanie się Józefa egipskiego oraz Jakuba z synami na dłuższy czas do Egiptu, również ze względu na głód w poprzednim miejscu zamieszkania. Podobnie jak dla patriarchów, Egipt stał się miejscem ocalenia również dla Świętej Rodziny - miejscem ocalenia przed Herodem.

Natomiast w pamięci wyznawców judaizmu Egipt zapisał się bardziej jako miejsce ucisku. Stało się tak ze względu na długie doświadczenie niewolnictwa, które spotkało Izraelitów w tym kraju. Należy zauważyć, że ostateczne wyzwolenie Izraelitów z niewoli egipskiej za pośrednictwem Mojżesza wywarło tak wielki wpływ na tożsamość żydowska, że Żydzi zawsze rozważali i nadal rozważają swoje losy w świetle wyjścia z Egiptu. Prelegent podkreślił, że w literaturze rabinicznej znajdujemy ciekawe przekonanie, że gdy w końcu przyjdzie Mesjasz, to będzie on jakby nowym Mojżeszem, podobnym w swoich dziejach do pierwszego Mojżesza. Ten nowy Mojżesz zaprowadzi naród wybrany do nowej ziemi obiecanej, gdzie będzie panował jako mesjański król.

W dalszej części wykładu ks. Stefański przypomniał, że już św. Jan Chryzostom zauważył, że Egipt na zachodzie oraz Babilonia na wschodzie reprezentowały dla starożytnych cały świat. Stąd św. Jan Chryzostom wnioskuje, że Bóg przywołał z terenu byłej Babilonii Mędrców z darami dla nowo narodzonego Mesjasza, a Mesjasza wraz z Józefem i Maryją posłał do Egiptu. Uczynił to, aby w ten sposób zapowiedzieć nawrócenie Wschodu i Zachodu, czyli całego świata.

Prelegent, odwołując się do Księgi Wyjścia, zauważył, że ocalenie Mojżesza dzięki egipskiej osobie z dworu faraona jest ważnym szcze- 
gółem zapowiadającym sytuację Jezusa, który jako nowy Mojżesz wraz z Maryją i św. Józefem też znajdzie gościnę na ziemi egipskiej. Podobnie jak pierwszy Mojżesz został uchroniony przed faraonem, tak też Jezus, jako Mesjasz i nowy Mojżesz, zostaje uchroniony przed Herodem, czyli przed nowym faraonem. Ksiądz dr Jacek Stefański przywołał jeszcze inne szczegóły, które łączyły Mojżesza i wyjście narodu wybranego z Egiptu z ucieczką i powrotem Świętej Rodziny z Egiptu. Wyjście z niewoli egipskiej oraz ucieczka Józefa wraz z Jezusem i Maryją dokonały się w nocy. Dla Ewangelisty noc udania się Świętej Rodziny do Egiptu była zapowiedziana przez nocną ucieczkę Izraelitów z Egiptu. Można powiedzieć, że wyjście Izraelitów z Egiptu oraz ich ucieczka od faraona była zapowiedzią nowego wyjścia, jakim było wyjście Świętej Rodziny z Judei do Egiptu. Zestawienie tekstów biblijnych z Księgi Wyjścia i z Ewangelii św. Mateusza pokazuje wyraźne podobieństwo między sytuacją Mojżesza a sytuacją Józefa, który jest jakby Nowym Mojżeszem. Prelegent zauważył jednocześnie, że św. Józef wprowadził Jezusa w mesjańską rolę nowego Mojżesza. Zanim Jezus stał się nowym Mojżeszem, rolę nowego Mojżesza musiał pełnić, przynajmniej tymczasowo, św. Józef.

W ostatniej części swojego wystąpienia ks. Stefański ukazał św. Józefa jako wiernego syna Boga Ojca, który został wybrany na Opiekuna Syna Bożego. Św. Józef wypełnił wolę Boga Ojca w sposób doskonały pod każdym względem. Św. Mateusz posłużył się aż dziesięcioma czasownikami w odniesieniu do św. Józefa. Uczynił tak, ponieważ jest to liczba, która u każdego wyznawcy judaizmu kojarzy się z Egiptem i z przebywaniem Izraelitów na pustyni, po wyjściu z Egiptu (10 plag, 10 przykazań). Natomiast, przywołując proroctwa Izajasza, prelegent stwierdził, że prorok mówił o błogosławieństwie Bożym dla Egiptu. Niezbędną rolę w tym wszystkim odgrywał św. Józef, gdyż to on prowadził wcielonego Syna Bożego do Egiptu, aby przygotować ten pogański kraj do przyjęcia Ewangelii. Obecnie koptyjscy chrześcijanie w Egipcie są przekonani, że gdy św. Józef przyprowadził Jezusa i Maryję do Egiptu, uczynił ziemię egipską podatną na początkową łaskę ewangelizacji tego kraju. W Egipcie można dzisiaj zobaczyć liczne koptyjskie sanktuaria związane z przebywaniem tam Świętej Rodziny. Koptowie do dnia dzisiejszego podkreślają nie tyle aspekt ucieczki Świętej Rodziny do Egiptu, ile jej „wejście” do Egiptu $\mathrm{w}$ celu rozpoczęcia tam dzieła ewangelizacji. Sam Bóg chciał, aby św. Józef wprowadził Jezusa-Mesjasza do Egiptu i wyprowadził Go stamtąd do ziemi Izraela. $W$ ten sposób Bóg Ojciec zapragnął, aby św. 
Józef był niezbędnym przewodnikiem przygotowującym nas wszystkich i cały świat na spotkanie z Jezusem.

Trzecim prelegentem była Dominique Boyer-Lemoine, matka trojga dzieci, w tym dziewczynki z zespołem Downa, profesor literatury. Przed emeryturą zaangażowała się w służbę św. Józefowi w Lyonie jako przewodnik Fundacji Fourvičre. Razem z księdzem Nicolas de Boccardem założyła grupę modlitewną w szkole św. Józefa. W swoim referacie mówiła o wychowaniu do wiary jako pierwszym kroku ku Nowej Ewangelizacji. Na początku swojego wystąpienia prelegentka zauważyła, że wychowanie do wiary jest równoznaczne z zaufaniem Bogu, który nas kocha, pierwszy pokłada w nas ufność i nieustannie przywraca właściwą relację z Nim. Tę misję powierzoną przez Boga należy przyjąć z pokorą, radością i wiarą, jak zrobili to Maryja i Józef.

Pani Dominique Boyer-Lemoine zwróciła uwagę, że kryzys rodziny, który możemy obserwować już od kilkudziesięciu lat, towarzyszy kryzysowi wychowania. Struktura rodziny ulega rozpadowi, co przejawia się $\mathrm{w}$ desakralizacja małżeństwa, rozwodach itp. Współczesna rodzina traci swoją zasadność i wagę moralną. Dlatego też relacje w rodzinie stają się coraz trudniejsze. Przemiany społeczne powodujące ogromne przywiązanie do pracy i sukcesu materialnego zatarły punkty odniesienia i właściwe relacje $\mathrm{w}$ rodzinach. Bardzo często zdarza się, że ojciec fizycznie jest obecny $\mathrm{w}$ rodzinie, ale praktycznie nie uczestniczy $\mathrm{w}$ wychowaniu i życiu codziennym dziecka. Zadaniem ojca w rodzinie jest nauka i odkrywanie granic, które są niezbędne dla właściwego kształtowania dziecka. Ojciec, po szkole miłości matczynej, jest drugą szkołą dla dziecka. To on przekazuje wiarę, on wychowuje, on uczy. Rodzina, w której brakuje nauczania ojca, zatraca swój punkt odniesienia. W Europie, na skutek trzech ostatnich wojen, $\mathrm{w}$ wielu rodzinach matki stawały się głową rodziny.

Podobnie jak rodzina, również system edukacji został dotknięty kryzysem. Symboliczna śmierć ojca sprawia, że świat, a w szczególności młodzi ludzie przekraczają coraz więcej granic, często zatracając się w przemocy bez jakichkolwiek hamulców. Nie należy więc dziwić się coraz częstszym aktom przemocy $\mathrm{w}$ szkołach popełnianym przez coraz to młodsze dzieci oraz swego rodzaju szalonemu poszukiwaniu skrajnej maskulinizacji w konfliktach społecznych i dramatach narodowych, co prowadzi do wypaczenia obrazu ojca. Zanik punktów odniesienia sprawil, że zaczęto szukać ojca we wszystkich jego postaciach, idolach, wzorcach - mówiła prelegentka. 
W dalszej części swojego referatu Pani Profesor wskazywała na sposoby wyjścia z tej kryzysowej sytuacji. Przypomniała najpierw, że ostatecznie mężczyzną jest się tylko z Boga, kobietą jest się tylko z mężczyzny, ale kobieta może być z mężczyzny jedynie wtedy, gdy mężczyzna jest $\mathrm{z}$ Boga. W tym miejscu dotykamy sensu nierozerwalności sakramentu małżeństwa, który jest oparty na wzajemnym dopełnianiu się mężczyzny i kobiety i ich wzajemnej miłości. Taki był od początku stwórczy zamysł Boga. W tajemnicy Wcielenia Bóg daje nam nową rodzinę jako wzór. Jest to rodzina Józefa i Maryi, której Bóg przekazał swojego Syna. Od tamtej chwili każda ludzka rodzina jest tajemniczo związana ze Świętą Rodziną, pierwszym Kościołem i zapowiedzią Kościoła niebieskiego.

Prelegentka podkreśliła, że św. Józef jest swego rodzaju remedium na to poczucie nicości, jako że on działa, żyje pojednany z Bogiem. Dzięki Józefowi, możemy przejść z naszej „dobroci ludzkiej” do szlachetnej cnoty „pokory”. Ojciec Niebieski przywrócił formę Pierwszego Stworzenia w Maryi i Józefie. W Nowym Przymierzu, gdzie wszystko jest stworzone na nowo, wszystko jest odrodzeniem, wszystko jest dobre i nowe! Jest Dobrą Nowiną. Oznacza to, że powinniśmy ponownie postawić Boga na pierwszym miejscu w naszym życiu i w centrum naszego powołania wychowawczego: żyć z Maryją i Józefem, by „wychować” Pana w naszym życiu. Powinniśmy prosić Maryję i Józefa, by „byli obecni” w naszych brakach, wspierając nas w podejmowaniu decyzji i w trudach życia. Musimy dać życiu rodzinnemu bogactwo, dzięki któremu każdy pozna smak odpowiedzialności, podnieść jakość wspólnie spędzonych chwil, doceniać rolę każdej osoby, dbać o jakość relacji, zainteresowanie drugim. Powinno się $\mathrm{w}$ nas pojawić zamiłowanie do świętowania i wreszcie trzeba poznać sens i smak przebaczenia, które jest nieodzowne we wspólnym życiu.

Pani Dominique Boyer-Lemoine mówiła także o wielkiej Pięćdziesiątnicy Miłości zapowiedzianej przez Martę Robin i nowych wspólnotach, które łączy kult Świętej Rodziny, a w szczególności św. Józefa. W tych wspólnotach dokonuje się uzdrowienie zranionego ojcostwa przez odkrycie na nowo Boga, będącego osobą, mówiącą i kochającą nas w Jego Domu. Te wspólnoty stają się miejscem wezwania do nawrócenia się do Ojca, aby móc przyjąć od Niego łaskę stania się synem, córką, ale również mężem, żoną, pracownikiem, przełożonym. Szczególną rolę w tym dziele nawrócenia, uzdrowienia i przemiany odgrywa św. Józef. On przedstawiany jest jako wzór dla ojców i mężczyzn. Istnieje dziewięć fundamentalnych rzeczy w wychowaniu „,według Józefa” w tradycji żydowskiej. Są to: wyżywić, czyli pozwolić dziecku żyć i wzrastać, 
rozwijać się, zapewnić równowagę materialną, psychologiczną i duchową całej rodziny; prowadzić, czyli być głową rodziny w pełnym tego słowa znaczeniu, decyzje konsultować, ale podejmować samodzielnie; chronić przed złem z troskliwością, odwagą i cierpliwością; uczyć, czyli przekazywać wiedzę i mądrość życiową, wspólnie się modlić, dawać świadectwo; dać pochodzenie na drodze przebaczenia i pogodzenia się z własną historią; nadać imię, czyli określić, przygotować do życiowej misji, budować poczucie pewności siebie u dziecka; przekazać swoje nazwisko, a wraz z nim wychowanie, tradycję i dziedzictwo; przekazać swój majątek; okazać miłosierdzie czy nauczyć się przebaczać sobie w rodzinie. $\mathrm{Na}$ tych fundamentach mężczyzna powinien budować swoje ojcostwo i wychowywać do wiary swoją rodzinę.

Gilles de Christen, kiedyś dyrektor przedsiębiorstwa, dziś autor książek o św. Józefie: Florilčge sur Saint Joseph i Saint Joseph, qui est-tu?, wygłosił referat „Lekcje Świętego Józefa dla naszego życia codziennego, aby być prawdziwym świadkiem". Pierwsza lekcja została zatytułowana: „być dobrze wcielonym”. Prelegent zauważył, że trudno sobie wyobrazić tajemnicę Wcielenia bez Józefa. Obecność Józefa pozwala Wcieleniu stać się tak "ludzkim”, tak na nasz obraz - z problemami, których możemy doświadczyć w naszym osobistym życiu. Józef odpowiedział na te problemy. Dlatego właśnie chrześcijanie nie mylą się, kiedy spontanicznie przywołują Józefa w konkretnych (a nie tylko materialnych) problemach ich życia codziennego. Święta Rodzina nie ukazuje nam „,ani wielkich czynów, ani cudów, które nas przekraczają" (Ps 130,1), jak wielu tego by oczekiwało od osób tak bliskich Trójcy Świętej. W tej Rodzinie życie jest zaskakująco proste i normalne. Słowa Chrystusa: „Posłałem ich do świata" (J 17,18), są konkretne.

Druga lekcja to zaufanie Bogu. Św. Józef doświadczał wielu trudności związanych z codziennym życiem: bezrobocie, ubóstwo, nędzne warunki mieszkaniowe. On doświadczył głodu, cierpiał szczególnie, gdy głodny był Jezus i Maryja. Mądrość wschodnia, bliższa Świętej Rodzinie niż nam, wie, że „nie wszystko buduje się w jeden dzień” i że "każdy dzień troszczy się sam o siebie" (Mt 6,34).

Wyobraźmy sobie warsztat z Nazaretu: Józef dotykał gwoździ, które nie chciały się wbić; często pracował na zewnątrz przy załamaniach pogody; często spotykał zrzędliwych klientów lub tych, którzy nie płacili, osoby, które go wyzyskiwały lub mówiły złe rzeczy o nim z czystej zazdrości; często musiał naprawiać w pośpiechu niezbędne narzędzia, lemiesze, naczynia gospodarstwa domowego. 
Mimo tych przeciwności Józef pracował z Jezusem w „pokoju serca". Józef oddał się Opatrzności Bożej, bo wiedział, że z Bogiem nie boi się niczego, bez względu na trudy i cierpienia, jakie Bóg dopuszcza w jego życie. To wyraźnie oznacza, że absolutnie żadne $\mathrm{z}$ tych cierpień nie może być dla niego "złem”, nie może być szkodliwe dla niego. To jest wielka lekcja, być może największa lekcja, jakiej nam udziela.

Lekcja trzecia związana jest z nauką sprawiedliwości. Sprawiedliwość odsyła nas do Józefa "Sprawiedliwego", czyli tego, który jest całkowicie posłuszny Bogu (Mt 1,19). Wypełnić, co sprawiedliwe, to uznać, że tylko Bóg przenika umysły i serca. Józef w pełni był mężem sprawiedliwym.

Czwarta lekcja odnosi się do życzliwości. Prelegent odwołał się do Hymnu do miłości św. Pawła. Biblia daje nam wielkie lekcje w tej dziedzinie. Ach! Jeżeli Kain by nie osądził Abla! To może wydawać się drugorzędne, a jednak kto może powiedzieć, że nigdy nie osądzał? (1 Kor 13,1-8). Uważa on, że we wszystkich fragmentach Hymnu słychać odniesienie do życzliwości: słowo, które preferuję lepiej niż słowo „miłość", ponieważ to jest bardziej dostępne. Aby być dobrym, to trzeba "zachowywać w sobie spokój duszy, ciszę i równość", mówi Psalm 130 cytowany powyżej, Psalm Józefa! Spokojna woda nie hałasuje, natomiast burza przeraża. Nie dotyka się serc, tak jak i nie sieje się Ewangelii poprzez hałas, ale w „szepcie wiatru”, jak Bóg z prorokiem Eliaszem. Zwrócił uwagę również na to, że nasza życzliwość pomoże nam wysłuchać innego, dając mu prawo do popełniania błędów i tym samym dając mu z czasem możliwość przemiany. Każda ludzka relacja musi być prawdziwą relacją "dobroci”, dzięki której możliwe jest odbudowanie relacji zaufania do innych. Będąc prawdziwie życzliwym, stajemy się uczniami Józefa i całej Świętej Rodziny.

Kolejna lekcja, której udziela nam św. Józef, to pokora. Jest to święty, który pozostaje ukryty, choć zajmuje obok Maryi najwyższe miejsce, jakie człowiek może mieć w sercu Boga. Lecz on nie „zadomowia się", podczas gdy my mamy tendencję do „zadomowiania się" w naszych nawykach, jak i w naszych przekonaniach, w tym przekonaniach naszej wiary. Józef pozostaje skromny. Pokora to podwójne błogosławieństwo, ubogich serca i cichych (Mt 5,3-4). Jezus odbył lekcję pokory w domu i w pracy w Nazarecie, gdzie Józef miał misję, aby umożliwić Mu wzrastanie. Można powiedzieć, że odbył ją w szkole Józefa.

Lekcja szósta dotyczy świadectwa. Ma to być świadectwo bardziej czynami niż słowami. Najlepszą ewangelizacją jest świadectwo naszego 
życia. Józef jest w tym mistrzem: milczy, ale działa; i przez to, co czyni, pokazuje, kim jest. Lekcja Józefa to świadczenie poprzez przykład. Jego Syn, nasz Pan, nakazał nam być „świadkami” (Dz 1,8b). Według Papieża Pawła VI „człowiek współczesny chętniej słucha świadków aniżeli nauczycieli. Jeśli słucha nauczycieli, to dlatego że są świadkami”. Zdarzyło mi się często usłyszeć prostą modlitwę, ale z wiarą, tak że miałem wrażenie słyszeć ją po raz pierwszy. To jest coś, co dotknęło mojego serca znacznie bardziej niż najpiękniejsze słowa.

Świadczyć to nie znaczy „działać” lub „mówić”. Jezus prosi nas, by "być", „aby być solą ziemi [...] i światłem świata” po to, aby nasza wiara, nasza nadzieja, a zwłaszcza nasza miłość były owocne. Do świadectwa potrzebne są wiara, nadzieja i przede wszystkim miłość. W tym kontekście prelegent wzywał, abyśmy czynili jak Józef, kochali poprzez czyny, służąc drugiej osobie.

Jako ostatnią lekcję Gilles de Christen wskazał prawdę. Realizacja poprzednich lekcji domaga się bycia w prawdzie. To właśnie ta otwartość na prawdę pozwoliła Józefowi zaakceptować ubóstwo żłóbka, wszystko, co mógł zaoferować swojej żonie i Bogu, który miał narodzić się w tym mieście, które było z rodziny królewskiej. Możemy usłyszeć, jak mówił do Maryi: „Nie znalazłem nic prócz wilgotnej jaskini. To nie jest za dobre. Moje serce krwawi na myśl, że nie mam nic innego do zaoferowania dla Ciebie, ciężarnej. Lecz Bóg znajdzie", jak powiedział Abraham do Izaaka ( $\operatorname{Rdz} 22,8)$.

Święta Rodzina nakazuje nam, abyśmy byli prawdziwi we wszystkim, czym żyjemy. Bycie w prawdzie czyni nas również bardziej ludzkimi. Musimy być bardziej autentyczni w naszych działaniach. Nie należy czynić prozelityzmu; lecz być w prawdzie.

Na zakończenie prelegent podkreślił, że wzorując się na Świętym Józefie i Świętej Rodzinie, aby żyć naszą własną wiarą, nie musimy opuszczać świata, lecz wręcz przeciwnie, pozostać „w świecie”, dobrze zakotwiczeni w naszym codziennym życiu. Wskazane lekcje stanowią solidne fundamenty, na których możemy i musimy się wesprzeć, aby żyć naszą wiarą na wzór "szkoły z Nazaretu”, i w ten sposób będziemy świadkami w naszej pracy, jak i w całym naszym życiu.

Ostatni referat zatytułowany „Święty Józef w doświadczeniu wiary i w przekazywaniu wiary (kontekst biblijny i egzystencjalny)" wygłosił Ryszard Montusiewicz, dziennikarz, publicysta, tłumacz, korespondent mediów polskich w Izraelu. Mąż i ojciec 9 dzieci. Razem z żoną zaangażowany od ponad 30 lat w doświadczenie Drogi Neokatechumenalnej. 
Wiele lat był wykładowcą na UMCS i KUL w Lublinie, ostatnio wykładowcą w Wyższej Szkole Dziennikarstwa w Lublinie i w Wyższej Szkole Filologii Hebrajskiej w Toruniu. Przewodnik po Ziemi Świętej. Członek Komitetu Episkopatu Polski ds. Dialogu z Judaizmem.

W swoim referacie prelegent zwrócił uwagę, że cały czas poznajemy Józefa w drodze. Józef przenosi Jezusa w życie, daje mu swe silne ramiona i poczucie bezpieczeństwa. Józef umiał rozpoznać głos Anioła, który usłyszał w głębi swego lęku i zwątpienia. On rozpoznał to, co Bóg do niego mówi, i pozostał wierny tej misji mężczyzny, opiekuna, ojca, przekazując dorastającemu w Nazarecie Jezusowi wiarę, którą sam otrzymał od swoich ojców.

W tle Nazaretu widzimy św. Józefa, który jest oblubieńcem Maryi, ziemskim opiekunem Jezusa, głową tej rodziny. Ryszard Montusiewicz w tym miejscu odwołał się do homilii papieża Pawła VI, wygłoszonej w Nazarecie w styczniu 1964 roku. Papież powiedział wtedy, że musimy sobie przyswoić kilka pouczeń z Nazaretu. Szkoła Nazaretu, szkoła Świętej Rodziny to lekcja milczenia, lekcja życia rodzinnego, przykład pracy. To też lekcja ojcostwa. Poznajemy Józefa, który milczy, ale jednocześnie słucha i odpowiada konkretnymi faktami, dlatego nosić w sobie doświadczenie Józefa to nosić w sobie doświadczenie mocy Boga. Stąd trzeba zaznaczyć, że pobożność Józefowa jest ważna, ale może ważniejsze jest nosić w sobie doświadczenie wiary Józefa. Józef ją otrzymał i przekazał ją dalej. Ta wiara pomogła mu przyjmować kolejne doświadczenia, ponieważ po ludzku to, co spotyka Józefa, jest czymś, co go przekracza. Jednak Józef jest człowiekiem wiary, jest sprawiedliwy, pobożny, rozpoznaje głos Boga, który do niego mówi, i to sprawia, że we wszystkim wypełnia wolę Bożą.

Kolejnym wydarzeniem, którego Józef, gdyby nie był człowiekiem wiary, nie umiałby przyjąć, to odrzucenie i nieprzyjęcie jego i brzemiennej Maryi w Betlejem. Józef, pochodzący z rodu Dawida, został odrzucony przez swoich krewnych i bliskich. Było to upokarzające doświadczenie i na pewno bardzo bolesne dla Józefa jako mężczyzny, jako członka tego rodu, jako głowy tej rodziny. Jednak on przyjął wszystko w milczeniu.

Trzecim doświadczeniem pokazującym egzystencjalny wymiar wiary było ofiarowanie w świątyni. Tam Józef jeszcze bardziej był świadomy tego, kim jest Jezus, i usłyszał, że też jego duszę, jego serce, jego osobiście i bardzo głęboko dotknie to, co dotyczy Jezusa, „,aby na jaw wyszły zamysły serc wielu".

Józef jest dla nas świadkiem wiary i świadkiem nowej ewangelizacji, ponieważ on zaświadcza o Bogu, który jest żywy, który przeprowa- 
dza, o Bogu, który okazuje swoją moc i który potrafi kochać. Św. Józef jest także przykładem prawdziwej pokory, która kładzie fundament pod prawdziwą męską godność i odpowiedzialność, bo w tym upokorzeniu, w tej pokorze jest gotowość oddania życia za drugą osobę. Takim człowiekiem jest św. Józef, który tego uczył Jezusa. Taki też jest Jezus, który jest gotowy oddać życie za każdego z nas i pokazuje, że w tym nie ma śmierci, że w tym można uzyskać życie na nowo, radość, satysfakcję, czułość, bliskość relacji do Boga.

Sympozja Józefologiczne organizowane każdego roku w Kaliszu stały się wydarzeniem adresowanym nie tylko do duchownych naukowców, józefologów i badaczy, ale również do osób świeckich, których zafascynowała postać św. Józefa. Tak było także podczas 43. Sympozjum Józefologicznego, w którym uczestniczyło wielu świeckich z całej Polski. Warto zaznaczyć, że spośród pięciu prelegentów trzech było osobami świeckimi, których praca naukowa nie jest głównym zajęciem. Trzeba jednak czuwać, by prezentowane referaty miały wymiar naukowy, a nie kaznodziejski. Założeniem Polskiego Studium Józefologicznego jest bowiem pogłębianie i budowanie teologii józefologicznej. Oczywiście, wymiar pastoralny nie może być pominięty, ale nie może stać się dominujący. 